\title{
Comparison of soft and hard tissue changes between symmetric and asymmetric extraction patterns in patients undergoing orthodontic extractions
}

\section{Porównanie zmian tkanek miękkich i twardych pomiędzy metodami ekstrakcji symetrycznej i asymetrycznej u pacjentów leczonych ekstrakcyjnie ze wskazań ortodontycznych}

\author{
Sarah Irfan ${ }^{A-D}$, Mubassar Fida ${ }^{\mathrm{E}, \mathrm{F}}$ \\ Section of Dentistry, Department of Surgery, Aga Khan University Hospital, Karachi, Pakistan \\ A - research concept and design; B - collection and/or assembly of data; $C$ - data analysis and interpretation; \\ $D$ - writing the article; $E$ - critical revision of the article; $F$ - final approval of the article
}

Address for correspondence

Sarah Irfan

E-mail: sarahirfan88@yahoo.com

\section{Funding sources}

None declared

Conflict of interest

None declared

Received on March 29, 2019

Reviewed on April 26, 2019

Accepted on May 22, 2019

Published online on September 30, 2019

Cite as

Irfan S, Fida M. Comparison of soft and hard tissue changes between symmetric and asymmetric extraction patterns in patients undergoing orthodontic extractions. Dent Med Probl. 2019;56(3):257-263. doi:10.17219/dmp/109568

DOI

$10.17219 / \mathrm{dmp} / 109568$

Copyright

๑) 2019 by Wroclaw Medical University

This is an article distributed under the terms of the

Creative Commons Attribution 3.0 Unported License (CC BY 3.0)

(https://creativecommons.org/licenses/by/3.0/)

\begin{abstract}
Background. Orthodontic treatment modalities and biomechanics are important factors influencing soft and hard tissues.

Objectives. The aim of this study was to compare soft and hard tissue changes after implementing asymmetric and symmetric extraction patterns.

Material and methods. A retrospective cross-sectional study was conducted using the orthodontic files of 62 patients from the dental clinics of a tertiary care hospital. Patients were divided into 2 groups, each of 31 patients. Group 1 referred to the symmetric extraction patterns (SEP), whereas group 2 regarded the asymmetric extraction patterns (AEP). TheWilcoxon signed-rank test was used to determine differences between the initial and final cephalometric parameters. The Mann-Whitney U-test was used to compare the treatment changes between SEP and AEP. The SEP and AEP groups were divided into subgroups for further analyses. The Kruskal-Wallis test was used to determine significant differences in the cephalometric changes among the different subgroups. In order to further establish inter-group differences, a pairwise comparison between the subgroups was made using the Mann-Whitney U-test.

Results. In the symmetric group, the pre- and post-treatment values for all soft tissue variables, upper incisor-sella-nasion plane angle (UI-SN), lower incisor mandibular plane angle (L-IMPA), and Frankfurtmandibular plane angle (FMA) showed significant differences $(p \leq 0.05)$. In the asymmetric group, none of the soft tissue parameters showed any significant difference in the pre- and post-treatment values; however, FMA and L-IMPA differed significantly $(p \leq 0.05)$. The parameters UI-SN and FMA as well as all soft tissue variables except Z-angle (Z), were significantly different between the SEP and AEP groups. The medians and interquartile ranges (IQRs) of the cephalometric changes among the subgroups were compared using the Kruskal-Wallis test. All soft tissues parameters except Z showed significant differences.

Conclusions. The symmetric extraction patterns leads to a greater change in the patient's profile, whereas asymmetric extractions can be carried out to remedy occlusal discrepancies without the risk of profile flattening. While employing premolar extractions aiming to reduce the facial height, due consideration with respect to biomechanics must be given.
\end{abstract}

Key words: tooth extraction, incisor, premolar

Słowa kluczowe: ekstrakcja zęba, siekacz, ząb przedtrzonowy 


\section{Introduction}

One of the most essential reasons why patients seek orthodontic treatment is to improve their facial appearance. ${ }^{1,2}$ The patient's profile is predominantly associated with ideal facial esthetics. A convex profile with an unesthetic display of incisors at rest and procumbent lips is displeasing. In such a case, an orthodontist faces a dilemma whether to extract the teeth or not. The employment of either of the 2 treatment modalities (extraction or nonextraction) has been a debatable issue..$^{3,4}$ Treating patients with balanced soft tissue profiles becomes even more difficult. In such cases, discrepancies in dental parameters such as crowding, rotations or increased incisal inclinations may lead to an extraction decision for long-term stability.

Another leading reason for extractions is the dentoalveolar protrusion in patients with normal skeletal bases. Closing extraction spaces by retracting the anterior teeth can significantly improve dental inclinations and the soft tissue profile. The extractions of all first premolars, or upper first and lower second premolars are employed in the cases with the bimaxillary dental protrusion. Skeletal dysplasias, e.g., maxillary prognathism, may produce certain features, like procumbent soft tissues and protrusive anterior dentition, which leads to an excessive display of the gingivae, lip incompetency and the tension of the mentalis muscle on lip closure. Premolar extractions are often required to remedy such problems. ${ }^{5,6}$

Asymmetric extraction patterns (AEP) can be chosen when one or more teeth are congenitally missing, ${ }^{7,8}$ an asymmetric molar relationship is present, the facial midline is deviated, or significant dental arch asymmetries are present. ${ }^{9}$ Asymmetric extraction therapy in Class II malocclusion may require only 1 premolar extraction or 3 premolar extractions. Mandibular incisor extraction is an alternative option to the extraction of lower premolars in carefully selected cases, such as Class I malocclusion with moderate crowding in the lower anterior teeth and little or no crowding in the upper arch, cases with midline deviation, Bolton's discrepancy, increased lower incisor inclination, Class III incisal relationship, and cases with minimal overbite and overjet. ${ }^{10-12}$ The important advantages of this option are as follows: a harmonious profile can be maintained; treatment time and cost may be reduced; and more stable results can be achieved.

Implementing treatment modalities that maintain the facial equilibrium while correcting occlusal disharmonies involves an unceasing learning process. ${ }^{13}$ Differences in treatment modalities and biomechanics are important factors influencing soft tissues. ${ }^{14}$ Changes in the soft-tissue contour result from the interplay between certain anatomical and functional variables, including lip length and thickness, the architecture and function of facial muscles, and ethnicity. ${ }^{15-17}$ The change in dental inclinations and the resulting alteration of the lip position, achieved with orthodontic treatment, has been extensively studied. ${ }^{18-21}$
However, most studies have compared the profile changes in extraction vs non-extraction treatment modalities. ${ }^{22,23}$ In the present study, we compared the changes in the hard and soft tissue parameters after implementing AEP and symmetric extraction patterns (SEP).

\section{Material and methods}

This cross-sectional study was approved by the Ethical Review Committee of Aga Khan University Hospital in Karachi, Pakistan. The sample size was calculated considering $80 \%$ as power of the study at a significance level of $5 \%$. This revealed that a minimum of 31 individuals were necessary in each of the 2 groups. Therefore, 62 patients of Pakistani origin reporting for orthodontic treatment were retrospectively selected from the files of the orthodontic department. These patients, treated between 2008 and 2014, were divided into 2 groups, according to their treatment approach. Group 1 consisted of 31 patients treated with SEP, whereas group 2 consisted of 31 patients treated with AEP. The symmetric group included patients with the extraction of all first premolars (all 4's), or upper first and lower second premolars (upper 4's, lower 5's). The asymmetric group included patients with the extraction of 3 premolars in any combination or a single lower incisor extraction.

The inclusion criteria comprised patients aged $\geq 12$ years undergoing orthodontic treatment with planned extractions, presence of all maxillary and mandibular permanent teeth up to second molars, and complete orthodontic records. The exclusion criteria were the following: presence of any supernumerary or impacted tooth; any history of facial trauma or previous orthodontic treatment; and syndromic or isolated cleft lip and palate (CLP) patients.

All patients were treated with preadjusted fixed appliances $\left(0.022 \times 0.028^{\prime \prime}\right)$, slotted by postgraduate students trained by the same supervisor. The wire sequence began with 0.012 " nitinol (NiTi) archwires, followed by 0.014 ", 0.016 " and $0.018^{\prime \prime}$ ones. Leveling was achieved using the accentuated and/or reversed curve of Spee archwires. In the cases of premolar extractions, the retraction of canines was carried out with 0.018 " stainless steel (SS) archwires. After the canine retraction, the incisor retraction was done with $0.017 \times 0.025$ " SS bull loop. Class II elastics were used for minor anteroposterior adjustments at the final stages with $0.017 \times 0.025$ " SS archwires. Pre- and post-treatment cephalometric radiographs were taken, and tracings were done using transparent 0.003 " acetate paper and $0.03 \mathrm{~mm} \mathrm{HB}$ lead pencil. Each radiograph was manually traced by the same operator. The soft tissue parameters measured were as follows: E-line-upper and lower lip distance (EU and EL, respectively); S-line-upper and lower lip distance (SU and SL, respectively); Z-angle $(\mathrm{Z})$; and nasolabial angle $(\mathrm{NL})$. The skeletal parameters measured were as follows: sella-nasion plane-point A angle (SNA); sella-nasion plane-point B angle (SNB); 
point A-point B angle (ANB); facial angle (FA); sella-nasion plane-gonion-gnathion plane angle (SN-GoGn); and Frankfurt-mandibular plane angle (FMA). The dental parameters measured were upper incisor-sella-nasion plane angle (UI-SN) and lower incisor-mandibular plane angle (L-IMPA). All angular measurements were made to the nearest $0.5^{\circ}$ and the linear measurements - to $0.5 \mathrm{~mm}$. To identify any intra-examiner error, 10 radiographs were randomly selected and retraced by the same investigator after an interval of 1 week. The intraclass correlation coefficient (ICC) was used to evaluate the level of agreement, which proved to be excellent $(0.8-0.9)$ for all variables.

The data was analyzed using IBM SPSS Statistics for Windows, v. 19 (IBM Corp., Armonk, USA). Descriptive statistics, e.g., frequencies and proportions, were calculated. The applied Kolmogorov-Smirnov test showed that the data had a non-normal distribution. Medians and interquartile ranges (IQRs) for each variable were calculated for each group. To determine significant differences between the initial and final cephalometric parameters, the Wilcoxon signed-rank test was used. The Mann-Whitney $U$-test was applied to compare the treatment changes between the SEP and AEP groups.

The SEP and AEP groups were divided into subgroups for further analyses. The Kruskal-Wallis test was used to determine significant differences in the cephalometric parameters among the different subgroups. In order to further determine inter-group differences, a pairwise comparison between the subgroups was made using the Mann-Whitney $U$-test.

The difference in cephalometric parameters, calculated by subtracting the post-treatment cephalometric mea- surements from the pre-treatment values, was appropriately indicated by signs + or - .

A $p$-value $\leq 0.05$ was considered statistically significant.

\section{Results}

The SEP group consisted of 31 patients with mean age of $18.62 \pm 7.64$ years, whereas AEP group consisted of 31 patients with mean age of $16.80 \pm 4.40$ years.

The frequency of different extraction patterns in the SEP and AEP group is shown in Table 1.

In the SEP group, the pre- and post-treatment values for all soft tissue variables, i.e., EU, EL, SU, SL, Z, and NL, were significantly different $(p<0.001)$. Both dental variables, i.e., UI-SN and L-IMPA, were also significantly different ( $p \leq 0.05$ and $p \leq 0.001$, respectively), whereas among the skeletal variables, only FMA showed a statistically significant difference in the pre- and post-treatment assessment $(p \leq 0.001)$ (Table 2).

Table 1. Frequency of different extraction patterns in the symmetric and asymmetric groups

\begin{tabular}{|c|l|c|}
$\begin{array}{c}\text { Extraction } \\
\text { group }\end{array}$ & \multicolumn{1}{|c|}{ Extraction pattern } & $\begin{array}{c}\text { Frequency } \\
\mathrm{n}(\%)\end{array}$ \\
\hline \multirow{3}{*}{ Symmetric } & all first premolars & $27(87.1)$ \\
& upper first and lower second premolars & $4(12.9)$ \\
& total & $31(100)$ \\
Asymmetric & single lower incisor & $24(77.4)$ \\
& total & $7(22.6)$ \\
& & $31(100)$ \\
\hline
\end{tabular}

Data presented as number (percentage).

Table 2. Pre- and post-treatment changes in the cephalometric parameters in the symmetric extraction patterns (SEP) and asymmetric extraction patterns (AEP) groups

\begin{tabular}{|c|c|c|c|c|c|c|c|c|c|c|}
\hline \multirow{3}{*}{ Parameter } & \multicolumn{4}{|c|}{ Asymmetric extraction } & \multirow{3}{*}{$p$-value } & \multicolumn{4}{|c|}{ Symmetric extraction } & \multirow{3}{*}{$p$-value } \\
\hline & \multicolumn{2}{|c|}{ pre-treatment } & \multicolumn{2}{|c|}{ post-treatment } & & \multicolumn{2}{|c|}{ pre-treatment } & \multicolumn{2}{|c|}{ post-treatment } & \\
\hline & median & IQR & median & IQR & & median & IQR & median & IQR & \\
\hline $\mathrm{EU}[\mathrm{mm}]$ & -3.00 & $-6.00,-2.00$ & -3.00 & $-5.00,-2.00$ & 0.586 & -1.00 & $-3.00,1.00$ & -4.00 & $-5.00,-2.00$ & $0.000^{* *}$ \\
\hline$E L[\mathrm{~mm}]$ & 1.00 & $-2.00,2.00$ & 0.00 & $-2.00,2.00$ & 0.854 & 2.00 & $-2.00,4.00$ & -1.00 & $-3.00,1.00$ & $0.000 * *$ \\
\hline $\mathrm{SU}[\mathrm{mm}]$ & 1.00 & $0.00,2.00$ & 0.00 & $-1.00,2.00$ & 0.161 & 2.00 & $0.00,4.00$ & 0.00 & $-2.00,1.00$ & $0.000^{* *}$ \\
\hline $\mathrm{SL}[\mathrm{mm}]$ & 3.00 & $2.00,4.00$ & 3.00 & $1.00,4.00$ & 0.818 & 4.00 & $1.00,6.00$ & 1.00 & $-1.00,3.00$ & $0.000^{* *}$ \\
\hline$Z\left[^{\circ}\right]$ & 63.00 & $60.00,72.00$ & 68.00 & $62.00,75.00$ & 0.148 & 64.00 & $56.00,72.00$ & 68.00 & $64.00,74.00$ & $0.001^{* *}$ \\
\hline $\mathrm{NL}\left[{ }^{\circ}\right]$ & 105.00 & $95.00,109.00$ & 100.00 & $95.00,107.00$ & 0.553 & 97.00 & $90.00,105.00$ & 105.00 & $94.00,114.00$ & $0.001^{* *}$ \\
\hline SNA $\left[^{\circ}\right]$ & 80.00 & $78.00,84.00$ & 80.00 & $79.00,83.00$ & 0.171 & 82.00 & $79.00,83.00$ & 82.00 & $80.00,83.00$ & 0.388 \\
\hline SNB $\left[^{\circ}\right]$ & 76.00 & $75.00,80.00$ & 77.00 & $75.00,79.00$ & 0.758 & 77.00 & $75.00,79.00$ & 77.00 & $74.00,79.00$ & 0.933 \\
\hline ANB $\left[^{\circ}\right]$ & 3.00 & $2.00,5.00$ & 3.00 & $2.00,5.00$ & 0.283 & 4.00 & $3.00,6.00$ & 4.00 & $3.00,5.00$ & 0.951 \\
\hline $\mathrm{FA}\left[{ }^{\circ}\right]$ & 87.00 & $85.00,89.00$ & 88.00 & $83.00,91.00$ & 0.535 & 85.00 & $82.00,87.00$ & 86.00 & $82.00,87.00$ & 0.908 \\
\hline SN-GoGn $\left[^{\circ}\right]$ & 32.00 & $30.00,34.00$ & 32.00 & $29.00,35.00$ & 0.322 & 33.00 & $30.00,36.00$ & 32.00 & $28.00,35.00$ & 0.284 \\
\hline FMA $\left[^{\circ}\right]$ & 23.00 & $22.00,27.00$ & 25.00 & $22.00,29.00$ & $0.021^{*}$ & 27.00 & $26.00,31.00$ & 28.00 & $25.00,30.00$ & $0.000^{* *}$ \\
\hline UI-SN [] & 105.00 & $102.00,111.00$ & 107.00 & $100.00,108.00$ & 0.930 & 110.00 & $105.00,117.00$ & 102.00 & $96.00,105.00$ & $0.002^{*}$ \\
\hline L-IMPA [] & 101.00 & $96.00,103.00$ & 96.00 & $90.00,105.50$ & $0.029^{*}$ & 101.00 & $95.00,105.00$ & 95.00 & $92.00,100.00$ & $0.000^{* *}$ \\
\hline
\end{tabular}

IQR - interquartile range; EU - E-line-upper lip distance; EL - E-line-lower lip distance; SU - S-line-upper lip distance; SL - S-line-lower lip distance; Z - Z-angle; $\mathrm{NL}$ - nasolabial angle; SNA - sella-nasion plane-point A angle; SNB - sella-nasion plane-point B angle; ANB - point A-point B angle; FA - facial angle; SN-GoGn - sella-nasion plane-gonion-gnathion plane angle; FMA - Frankfurt-mandibular plane angle; UI-SN - upper incisor-sella-nasion plane angle; L-IMPA - lower incisor-mandibular plane angle; ${ }^{*} p \leq 0.05 ;{ }^{* *} p \leq 0.001$; the Wilcoxon signed-rank test. 
In the AEP group, none of the soft tissue parameters showed any significant difference in the pre- and posttreatment values. In the pre- and post-treatment assessment, a statistically significant difference was found in FMA among the skeletal variables and in L-IMPA among the dental variables $(p \leq 0.05)$ (Table 2$)$.

To compare the differences in the pre- and posttreatment values of all variables between the SEP and AEP groups, the Mann-Whitney $U$-test was applied and it showed that all soft tissue parameters except $\mathrm{Z}$ were significantly different between the SEP and AEP

Table 3. Comparison of the cephalometric changes between the symmetric extraction patterns (SEP) and asymmetric extraction patterns (AEP) groups

\begin{tabular}{|c|c|c|c|c|c|}
\hline \multirow{2}{*}{ Parameter } & \multicolumn{2}{|c|}{ Asymmetric extraction } & \multicolumn{2}{|c|}{ Symmetric extraction } & \multirow{2}{*}{$p$-value } \\
\hline & median & IQR & median & IQR & \\
\hline $\mathrm{EU}[\mathrm{mm}]$ & 0.00 & $-1.00,1.50$ & 2.00 & $0.00,3.00$ & $0.003^{*}$ \\
\hline $\mathrm{EL}[\mathrm{mm}]$ & 0.00 & $-1.00,2.00$ & 2.00 & $0.00,4.00$ & $0.001^{* *}$ \\
\hline $\mathrm{SU}[\mathrm{mm}]$ & 0.00 & $-1.00,2.00$ & 2.00 & $1.00,4.00$ & $0.002^{*}$ \\
\hline $\mathrm{SL}[\mathrm{mm}]$ & 0.00 & $-1.00,2.50$ & 3.00 & $1.00,4.00$ & $0.000^{* *}$ \\
\hline $\mathrm{Z}\left[^{\circ}\right]$ & -1.00 & $-4.00,1.00$ & -3.00 & $-9.00,0.00$ & 0.150 \\
\hline $\mathrm{NL}\left[{ }^{\circ}\right]$ & 0.00 & $-4.50,4.50$ & -8.00 & $-12.00,0.00$ & $0.001^{* *}$ \\
\hline SNA $\left[^{\circ}\right]$ & 0.00 & $-1.00,0.00$ & 1.00 & $-1.00,3.00$ & 0.070 \\
\hline SNB $\left[^{\circ}\right]$ & 0.00 & $-1.50,1.00$ & 0.00 & $-1.00,1.00$ & 0.977 \\
\hline ANB $\left[^{\circ}\right]$ & 0.00 & $-1.00,0.00$ & 0.00 & $0.00,1.00$ & $0.007^{*}$ \\
\hline $\mathrm{FA}\left[{ }^{\circ}\right]$ & 0.00 & $-2.50,1.00$ & 0.00 & $-1.00,2.00$ & 0.593 \\
\hline SN-GoGn [ $\left.{ }^{\circ}\right]$ & -1.00 & $-2.50,2.00$ & 0.00 & $-1.00,1.00$ & 0.518 \\
\hline FMA [ $\left.{ }^{\circ}\right]$ & -3.00 & $-3.00,0.50$ & 0.00 & $-1.00,3.00$ & $0.026^{*}$ \\
\hline UI-SN [] & 3.00 & $-7.50,7.00$ & 12.00 & $2.00,14.00$ & $0.000^{* *}$ \\
\hline L-IMPA [] & 2.00 & $-1.50,8.50$ & 5.00 & $0.00,9.00$ & 0.544 \\
\hline
\end{tabular}

${ }^{*} p \leq 0.05 ;{ }^{* *} p \leq 0.001$; the Mann-Whitney U-test. groups. Among the skeletal parameters, FMA and ANB, whereas among the dental parameters, UI-SN showed a significant difference between the SEP and AEP groups (Table 3).

The medians and IQRs of the cephalometric changes among the subgroups were compared using the Kruskal -Wallis test (Table 4). All soft tissues parameters except $\mathrm{Z}$ showed significant differences. Other parameters that differed significantly among the subgroups include ANB, FMA and UI-SN.

Table 5 shows a pairwise comparison of the cephalometric changes between the particular subgroups.

\section{Discussion}

The present study determined the soft as well as hard tissue alterations after different extraction patterns. Apart from the treatment modality, other factors, such as head posture, muscle function, weight, age, and gender, may also affect the interpretation of real soft tissue displacement. ${ }^{24,25}$ Careful diagnosis and treatment planning can eliminate undesirable changes in the soft tissue profile post-treatment. A relaxed lip posture during performing the cephalograms may reduce the variability and the strategic employment of technological advances, such as digital photography and videography, may help better determine the modality of choice. ${ }^{26}$

In a previous study of Class II cases, a greater reduction in maxillary incisor inclination was noticed in patients who were treated by extracting maxillary first premolars only as compared to those who were treated with all first premolar extractions. ${ }^{27}$

Table 4. Comparison of the cephalometric changes among different subgroups

\begin{tabular}{|c|c|c|c|c|c|}
\hline \multirow{3}{*}{ Parameter } & \multicolumn{2}{|c|}{ SEP } & \multicolumn{2}{|c|}{ AEP } & \multirow{3}{*}{$p$-value } \\
\hline & all 4's & upper 4's, lower 5's & lower incisor & 3 premolars & \\
\hline & \multicolumn{2}{|c|}{ median (IQR) } & \multicolumn{2}{|c|}{ median (IQR) } & \\
\hline $\mathrm{EU}[\mathrm{mm}]$ & $2.00(2.00,3.00)$ & $4.50(1.50,6.00)$ & $0.00(-1.00,0.75)$ & $2.00(-1.00,4.00)$ & $0.002^{*}$ \\
\hline $\mathrm{EL}[\mathrm{mm}]$ & $2.00(1.00,4.00)$ & $3.00(0.50,5.00)$ & $0.00(-1.75,1.00)$ & $2.00(2.00,2.00)$ & $0.004^{*}$ \\
\hline $\mathrm{SU}[\mathrm{mm}]$ & $2.00(1.00,4.00)$ & $3.50(0.50,5.00)$ & $0.00(-2.00,1.00)$ & $0.00(0.00,3.00)$ & $0.001^{* *}$ \\
\hline $\mathrm{SL}[\mathrm{mm}]$ & $3.00(1.00,4.00)$ & $5.50(0.25,7.00)$ & $0.50(-2.00,1.00)$ & $2.00(-1.00,3.00)$ & $0.001^{* *}$ \\
\hline$Z\left[^{\circ}\right]$ & $-3.00(-9.00,0.00)$ & $-12.50(-18.00,-1.75)$ & $-1.00(-4.00,0.00)$ & $-3.00(-4.00,4.00)$ & 0.172 \\
\hline $\mathrm{NL}\left[{ }^{\circ}\right]$ & $-7.00(-12.00,-7.00)$ & $-12.00(-13.50,-11.25)$ & $1.50(0.00,10.00)$ & $-8.00(-10.00,-4.00)$ & $0.000^{* *}$ \\
\hline SNA $\left[^{\circ}\right]$ & $1.00(-1.00,3.00)$ & $1.00(0.25,2.20)$ & $0.00(-1.00,0.00)$ & $1.00(0.00,1.00)$ & 0.053 \\
\hline $\mathrm{SNB}\left[^{\circ}\right]$ & $0.00(-1.00,1.00)$ & $1.50(-2.25,3.00)$ & $0.00(-2.75,1.00)$ & $0.00(-1.00,2.00)$ & 0.771 \\
\hline ANB $\left[^{\circ}\right]$ & $0.00(0.00,1.00)$ & $1.50(0.00,3.00)$ & $-1.00(-1.00,0.00)$ & $0.00(-1.00,1.00)$ & $0.009^{*}$ \\
\hline SN-GoGn $\left[^{\circ}\right]$ & $0.00(-1.00,1.00)$ & $-1.50(-3.00,1.50)$ & $0.00(-3.00,2.00)$ & $0.00(-4.00,1.00)$ & 0.647 \\
\hline FMA $\left[^{\circ}\right]$ & $0.00(-1.00,2.00)$ & $4.50(0.00,6.00)$ & $-1.00(-3.00,1.75)$ & $0.00(-1.00,0.00)$ & $0.042^{*}$ \\
\hline UI-SN [] & $12.00(2.00,14.00)$ & $25.00(25.00,32.00)$ & $-3.00(-9.50,5.00)$ & $9.00(5.00,10.00)$ & $0.000^{* *}$ \\
\hline L-IMPA $\left[^{\circ}\right]$ & $5.00(1.00,9.00)$ & $-6.00(-11.25,-1.50)$ & $3.50(-1.00,7.25)$ & $5.00(-6.00,10.00)$ & 0.047 \\
\hline
\end{tabular}

SEP - symmetric extraction patterns; AEP - asymmetric extraction patterns; ${ }^{*} p \leq 0.05 ;{ }^{* *} p \leq 0.001$; the Kruskal-Wallis test. 
Table 5. Pairwise comparison of the cephalometric changes between the subgroups

\begin{tabular}{|c|c|c|c|c|c|c|}
\hline \multirow{3}{*}{ Parameter } & \multicolumn{6}{|c|}{ Treatment modalities } \\
\hline & $\begin{array}{c}\text { all 4's } \\
\text { vs } \\
\text { U 4's, L 5's }\end{array}$ & $\begin{array}{c}\text { all 4's } \\
\text { vs } \\
\text { lower incisor }\end{array}$ & $\begin{array}{c}\text { all 4's } \\
\text { vs } \\
3 \text { premolars }\end{array}$ & $\begin{array}{c}\text { U 4's, L 5's } \\
\text { vs } \\
\text { lower incisor }\end{array}$ & $\begin{array}{c}3 \text { premolars } \\
\text { vs } \\
\text { lower incisor }\end{array}$ & $\begin{array}{c}3 \text { premolars } \\
\text { vs } \\
\text { U 4's, L 5's }\end{array}$ \\
\hline & \multicolumn{6}{|c|}{$p$-values } \\
\hline EU & 0.114 & $0.001^{*}$ & 0.667 & $0.005^{*}$ & 0.256 & 0.153 \\
\hline EL & 0.721 & $<0.001^{* *}$ & 0.076 & 0.230 & 0.280 & 0.557 \\
\hline SU & 0.570 & $<0.001^{* *}$ & 0.167 & $0.043^{*}$ & 0.195 & 0.174 \\
\hline SL & 0.246 & $<0.001^{* *}$ & 0.218 & $0.044^{*}$ & 0.105 & 0.122 \\
\hline Z & 0.147 & 0.154 & 0.564 & 0.063 & 0.668 & 0.128 \\
\hline $\mathrm{NL}$ & 0.076 & $<0.001^{* *}$ & 0.701 & $0.001^{*}$ & $0.002^{*}$ & $0.022^{*}$ \\
\hline SNA & 0.473 & 0.068 & 1.000 & $0.018^{*}$ & $0.026^{*}$ & 0.298 \\
\hline SNB & 0.450 & 0.817 & 0.539 & 0.386 & 0.532 & 0.564 \\
\hline ANB & 0.238 & 0.062 & 0.722 & $0.015^{*}$ & 0.113 & 0.242 \\
\hline FA & $0.050^{*}$ & 0.136 & 0.401 & 0.134 & 0.113 & $0.033^{*}$ \\
\hline SN-GoGn & 0.341 & 0.676 & 0.343 & 0.571 & 0.352 & 0.848 \\
\hline FMA & 0.098 & 0.062 & 0.282 & $0.015^{*}$ & 0.615 & 0.082 \\
\hline UI-SN & 0.124 & $<0.001^{* *}$ & 0.701 & $0.019^{*}$ & $0.005^{*}$ & 0.183 \\
\hline L-IMPA & $0.005^{*}$ & 0.248 & 0.814 & $0.025^{*}$ & 0.686 & 0.086 \\
\hline
\end{tabular}

$U$ - upper; $L$ - lower; ${ }^{*} p \leq 0.05$; ${ }^{* *} p \leq 0.001$; the Mann-Whitney U-test.

In the study conducted by Janson et al., the extraction of a single maxillary premolar was compared with the extraction of 2 maxillary and 1 mandibular premolars..$^{28}$ The latter group showed increased palatal tipping and dentoalveolar height of incisors after the treatment. ${ }^{28}$ In our results, UI-SN showed a significant variance between the SEP and AEP groups. A reduction in UI-SN was noted in the SEP group, whereas in the AEP group, an increase in the UI-SN inclination was found. This was due to the nonextraction approach in the upper arch, which resolved crowding in the maxilla at the expense of inclination.

In a similar study by Janson et al., the group which underwent the extraction of 2 maxillary and 1 mandibular premolars showed a reduction in L-IMPA, whereas the group in which the extraction of only 1 premolar was carried out showed the proclination of lower incisors. ${ }^{28}$ This could be attributed to the fact that crowding and the curve of Spee were managed without any mandibular extraction in that group..$^{29,30}$ In our study, L-IMPA showed a significant reduction in the post-treatment assessment of both groups and no significant difference was observed amid the SEP and AEP groups, as lower incisors were retracted in both groups. However, further SEP subgroup analysis showed that L-IMPA significantly differed between the "all 4's" and "upper 4's, lower 5's" extraction subgroups. The former group showed a decrease in L-IMPA, whereas an increase in L-IMPA was noted in the latter. This could be due to the fact that the "upper 4's, lower 5's" extraction pattern was employed in Class II molar cases, where the extraction spaces were predominantly utilized to correct the molar relationship rather than to affect L-IMPA.
Weyrich and Lisson noted that both EU and EL increased in both 4 premolars and 2 maxillary premolars extraction groups. ${ }^{27}$ Also, NL became obtuse, but the result was not significant. However, Janson et al. reported that EU decreased to a greater extent in the cases where 3 premolars had been extracted..$^{28}$ Our results showed a significant reduction in both EU and EL in the SEP group, whereas no significant change was noticed in the AEP group. The reason is that the asymmetric extractions, e.g., single maxillary premolar, 3 premolars in different quadrants or lower incisor are aimed to correct the occlusal discrepancies and the associated soft tissues remain unaffected. ${ }^{31}$

Scott Conley and Jernigan attained a reduction of $8 \mathrm{~mm}$ in the overjet, associated with a significant decrease in dental inclination and the lip profile, leading to an increase in NL. ${ }^{32}$ However, it was stated that the response of the lip contour was not consistent with the change in dental inclination; therefore, the possible alterations of the soft tissue profile should not cause any concern in the cases with dental discrepancies but with balanced soft tissues. ${ }^{32}$ Katsaros and Katsaros et al. also emphasized that the nasal and chin growth affect soft tissues, and those changes are more imperative than the effects of extraction patterns. ${ }^{33,34}$

Kirschneck et al. in their study of all first premolars extraction in borderline cases reported a significant decrease in SNA along with a reduction in incisor inclination, and no significant change in $\mathrm{SNB}^{35}$; our study showed no significant change in either.

Orthodoxly, one of the aims of premolar extraction may be to decrease the vertical facial height. However, in our study, we found that FMA significantly increased in both groups 
in the post-treatment assessment. While comparing the SEP and AEP groups, the difference was also significant and showed a greater increase in the asymmetric group. These findings are in concordance with the study conducted by Zafarmand and Zafarmand, where the bicuspid extraction theory (neither 2 nor 4 premolar extractions) for reducing the facial height did not provide any significant changes post-treatment. ${ }^{36}$ The vertical angle and the lower anterior facial height increased in both of their groups. This was also highlighted in a study conducted by Staggers, according to whom the biomechanical justification for this could be the intrinsic extrusive effect of most orthodontic modalities, e.g., the protraction of posterior teeth, which can unfavorably compensate any reduction in the facial height. ${ }^{37}$

This study was based primarily on the changes in soft and hard tissue parameters assessed on cephalometric images. It is now advocated that soft tissue changes should be evaluated with three-dimensional (3D) imaging techniques, both pre- and post-treatment, to correctly assess the treatment changes. There was an unequal distribution of extraction patterns in our groups, which could affect the results. A small sample size indicates that further studies need to be conducted to ensure that the results are generalizable to the population and that alternate treatment mechanics produce variable results.

\section{Conclusions}

The present study determined the alterations in soft and hard tissues after different extraction patterns. It can be concluded that a significant change in soft tissue parameters in the SEP group led to a greater improvement in the patient's profile. The inclinations of the upper and lower dentition can be improved in both the SEP and AEP groups, which may help position the teeth over the basal bone and enhance long-term stability. Asymmetric extractions can be carried out to remedy occlusal discrepancies without any risk of profile flattening. While employing premolar extractions aiming to reduce the facial height, due consideration with respect to biomechanics must be given.

\section{ORCID iDs}

Sarah Irfan (1) https://orcid.org/0000-0003-2598-052X

Mubassar Fida (1) https://orcid.org/0000-0003-4842-9896

\section{References}

1. Holdaway RA. A soft-tissue cephalometric analysis and its use in orthodontic treatment planning. Part I. Am J Orthod. 1983;84(1):1-28.

2. Peck H, Peck S. A concept of facial esthetics. Angle Orthod. 1970;40(4):284-318.

3. Holdaway RA. A soft tissue cephalometric analysis and its use in orthodontic treatment planning, Part II. Am J Orthod. 1984;85(4):279-293.

4. Young TM, Smith RJ. Effects of orthodontics on the facial profile: A comparison of changes during nonextraction and four premolar extraction treatment. Am J Orthod Dentofacial Orthop. 1993;103(5):452-458.
5. Beattie JR, Paquette $D E$, Johnston LE. The functional impact of extraction and non-extraction treatments: A long-term comparison in patients with "borderline", equally susceptible Class II malocclusions. Am J Orthod Dentofacial Orthop. 1994;105(5):444-449.

6. Hayashida H, loi H, Nakata S, Takahashi I, Counts AL. Effects of retraction of anterior teeth and initial soft tissue variables on lip changes in Japanese adults. Eur J Orthod. 2011;33(4):419-426.

7. Faerovig E, Zachrisson BU. Effects of mandibular incisor extraction on anterior occlusion in adults with Class III malocclusion and reduced overbite. Am J Orthod Dentofacial Orthop. 1999;115(2):113-124.

8. Proffit WR. Contemporary Orthodontics. $3^{\text {rd }}$ ed. St. Louis, MO: Mosby; 2000:251.

9. Melgaço CA, Araújo MTS. Asymmetric extractions in orthodontics. Dental Press J Orthod. 2012;17(2):151-156.

10. Bahreman AA. Lower incisor extraction in orthodontic treatment. Am J Orthod. 1977;72(5):560-567.

11. Kokich VG, Shapiro PA. Lower incisor extraction in orthodontic treatment. Four clinical reports. Angle Orthod. 1984;54(2):139-153.

12. Valinoti JR. Mandibular incisor extraction therapy. Am J Orthod Dentofacial Orthop. 1994;105(2):107-116.

13. Yogosawa F. Predicting soft tissue profile changes concurrent with orthodontic treatment. Angle Orthod. 1990;60(3):199-206.

14. Bishara SE, Cummins DM, Jakobsen JR, Zaher AR. Dentofacial and soft tissue changes in Class II, division 1 cases treated with and without extractions. Am J Orthod Dentofacial Orthop. 1995;107(1):28-37.

15. Kasai K. Soft tissue adaptability to hard tissues in facial profiles. Am J Orthod Dentofacial Orthop. 1998;113(6):674-684.

16. Subtelny JD, Sakuda M. Muscle function, oral malformation, and growth changes. Am J Orthod. 1966;52(7):495-517.

17. Oliver BM. The influence of lip thickness and strain on upper lip response to incisor retraction. Am J Orthod. 1982;82(2):141-149.

18. Drobocky OB, Smith RJ. Changes in facial profile during orthodontic treatment with extraction of four first premolars. Am J Orthod Dentofacial Orthop. 1989;95(3):220-230.

19. Talass MF, Talass L, Baker RC. Soft-tissue profile changes resulting from retraction of maxillary incisors. Am J Orthod Dentofacial Orthop. 1987;91(5):385-394.

20. Mamandras $\mathrm{AH}$. Linear changes of the maxillary and mandibular lips. Am J Orthod Dentofacial Orthop. 1988;94(5):405-410.

21. Guo Y, Han X, Xu H, Ai D, Zeng H, Bai D. Morphological characteristics influencing the orthodontic extraction strategies for Angle's class II division 1 malocclusions. Prog Orthod. 2014;15(1):44.

22. Lim HJ, Ko KT, Hwang HS. Esthetic impact of premolar extraction and nonextraction treatments on Korean borderline patients. Am J Orthod Dentofacial Orthop. 2008;133(4):524-531.

23. Moseling KP, Woods MG. Lip curve changes in females with premolar extraction or nonextraction treatment. Angle Orthod. 2004;74(1):51-62.

24. Burstone CJ. Lip posture and its significance in treatment planning. Am J Orthod.1967;53(4):262-284.

25. Zierhut EC, Joondeph DR, Artun J, Little RM. Long-term profile changes associated with successfully treated extraction and nonextraction Class II Division 1 malocclusions. Angle Orthod. 2000;70(3):208-219.

26. Maetevorakul S, Viteporn S. Factors influencing soft tissue profile changes following orthodontic treatment in patients with Class II Division 1 malocclusion. Prog Orthod. 2016;17:13.

27. Weyrich C, Lisson JA. The effect of premolar extractions on incisor position and soft tissue profile in patients with Class II, Division 1 malocclusion. J Orofac Orthop. 2009;70(2):128-138.

28. Janson G, Lenza EB, Francisco R, Aliaga-Del Castillo A, Garib D, Lenza MA. Dentoskeletal and soft tissue changes in class II subdivision treatment with asymmetric extraction protocols. Prog Orthod. 2017;18(1):39.

29. Bernstein RL, Preston CB, Lampasso J. Leveling the curve of Spee with a continuous archwire technique: A long term cephalometric study. Am J Orthod Dentofacial Orthop. 2007;131(3):363-371.

30. Millett DT, Cunningham SJ, O'Brien KD, Benson PE, de Oliveira CM. Treatment and stability of class II division 2 malocclusion in children and adolescents: A systematic review. Am J Orthod Dentofacial Orthop. 2012;142(2):159-169. 
31. Janson G, Carvalho PE, Cançado RH, de Freitas MR, Henriques JF. Cephalometric evaluation of symmetric and asymmetric extraction treatment for patients with Class II subdivision malocclusions. Am J Orthod Dentofacial Orthop. 2007;132(1):28-35.

32. Scott Conley R, Jernigan C. Soft tissue changes after upper premolar extraction in Class II camouflage therapy. Angle Orthod. 2006;76(1):59-65.

33. Katsaros $C$. Profile changes following extraction vs nonextraction orthodontic treatment in a pair of identical twins. J Orofac Orthop. 1996;57(1):56-59.

34. Katsaros $C$, Ripplinger $B$, Högel A, Berg R. The influence of extraction versus non-extraction orthodontic treatment on the soft tissue profile. J Orofac Orthop. 1996;57(6):354-365.

35. Kirschneck C, Proff P, Reicheneder C, Lippold C. Short-term effects of systematic premolar extraction on lip profile, vertical dimension and cephalometric parameters in borderline patients for extraction therapy - a retrospective cohort study. Clin Oral Investig. 2016;20(4):865-874.

36. Zafarmand AH, Zafarmand MM. Premolar extraction in orthodontics: Does it have any effect on patient's facial height? J Int Soc Prev Community Dent. 2015;5(1):64-68.

37. Staggers JA. Vertical changes following first premolar extraction. Am J Orthod Dentofacial Orthop. 1994;105(1):19-24. 